\title{
The effect of management quality of accounting information system outputs on customers satisfaction in Saudi Arabia commercial banks
}

\author{
Khaled Adnan Oweis ${ }^{\mathbf{a}^{*}}$
}

${ }^{a}$ Accounting Department, College Of Business Administration, Northern Border University,P.O.Box1321 Arar 91431 -Kingdom of Saudi Arabia

\begin{tabular}{l}
\hline C H R O N I C L E \\
\hline Article history: \\
Received September 26, 2021 \\
Received in revised format \\
October 292021 \\
Accepted December 22021 \\
Available online \\
December 172021 \\
\hline Keywords: \\
Management accounting systems \\
Quality accounting information \\
system \\
Customer satisfaction
\end{tabular}

\section{Introduction}

The aim of Saudi Arabia's 2030 vision is to develop a diversified and active financial market, to stimulate the development of the national economy and to diversify its revenue streams, and to stimulate savings, funding and investment through the development and deepening of financial sector institutions and the development of the Saudi financial system in a way that does not allow for the formation of an advanced financial market. Economic And globalization change from economics based on industry to economics on information have claimed corporate world management to be able to operate more effectively, efficiently and in control by placing forward excellence compete global and also local level goodness through the quality of human beings, yielded service and goods and also information technology.

Changes in economic and globalization from business, economics to knowledge-based economics have claimed that corporate world leadership is able to work more reliably, effectively and in charge by advancing competence to succeed globally and also locally by the standards of human beings, services and goods and even information technology, (Salehi et al., 2010; Saleh et al., 2021a). The emergence of technological developments has contributed to the automation of many jobs, including accounting. There are many digital tools that can be used in accounting processes without replacing the role

* Corresponding author.

E-mail address: oweiskhaled@yahoo.com (K. A. Oweis)

C 2022 Growing Science Ltd. All rights reserved.

doi: 10.5267/j.ac.2021.12.002 
of human factors in it (Bagranoff et al., 2010). This technology will provide many techniques that will reduce the manual data entry process and improve the speed, accuracy and quality of data. Techniques such as: the cloud and artificial intelligence, giving accountants many roles as advisors and analysts, as cloud accounting applications allow improving accounting information quality characteristics and increasing their ability to access financial data from any device that has the Internet through virtual simulation. As an integral part of an organizational structure, MAIS determines the organization's goals to track, encourage, review performance and also interact in order to engage and contribute to information (Bjørnenak \& Olson,1999). A crucial research challenge in the consistency of literature on the accounting information system (QAIS) relates to the capacity of management accounting systems (MAS) to offer information that lets managers make smarter choices (Situngkir \& Napitupulu, 2019; Corner,1989; Dalimunthe et al., 2018). Many scholars have advocated the use of more modern (QAIS) over the last decades. This paper analyzes the impact of the consistency of accounting information system performance control on customer loyalty in commercial banks in Saudi Arabia.

In marketing concepts, customer satisfaction is defined as an indicator of how the organization's goods or services meet the needs of consumers. This is one of the primary keys to ensuring the sustainability of business, since the loyalty of consumers in the future will decide the organization's business development. Satisfaction is determined by the quality of the goods, the quality of the service offered, the place where the product or service is bought, and the product or service price. Customer satisfaction can be defined as an appraisal focused on the cognitive processes corresponding to a distinction between the experience of customers and their original reference base. The first is an assessment of all service interactions and perceptions, while the latter is concerned with a single service encounter's post-purchase/consumption appraisal (Alananzeh et al., 2108). In order to explain customer behavior, most marketing analysis aims to rely on total satisfaction. However this definition does not capture transaction-specific interactions of customers that form quality or service (Jahmani et al., 2020; Jawabreh \& Sarayreh, 2017; Jawabreh et al., 2020). Customer satisfaction is overall satisfaction over each service contact experience, which presumably contributes to purchasing and continuing relationships with the brand. In the literature, the relationship between satisfaction-attachment is not definitive, revealing inconsistencies and ambiguities (Masadeh et al., 2019; Napitupulu, 2015). Researchers debated whether total or transaction-specific customer satisfaction) is a precedent of position attachment.

\section{Literature review}

To assess the quality of accounting information, there are several metrics that can be used. Accounting Information System (AIS), which includes the collection and storage of financial and accounting data for processing and providing it to internal users, and reporting information about investors, creditors, and taxes, is a way to track accounting activities through information technology resources in order to achieve the characteristics of the quality of accounting information. The SIS system combines the use of traditional accounting using generally accepted accounting principles with information technology resources, (Byrne\& Pierce,2007). The AIS system includes: revenue, expenditure data, and the information of customer, employees, and tax that must have the characteristics of the quality of the SIS required.

The data includes sales orders, analysis reports, purchase orders, invoices, verification and inventory records, payroll, ledger, experimental balance and balance information, which are stored in the SIS system database, and which have been pre-program in a way that handles these data for use, (Chenhall \& Morris,1986). The system also provides the ability to protect this information against viruses and hackers through cyber security that protects data stored electronically, while the output is in the form of reports that include accounts of debtors, fixed asset destruction schedules, and other information needed for financial reporting. It is therefore essential to ensure that the quality characteristics of SIS are met.

The benefits of the AIS system are reflected in the following: Interdepartmental communication; the AIS system enhances the ability to provide communication between different departments, where the sales department provides a sales budget, and the product management unit then uses this data to work on inventory counts and buy supplies (Davila \& Foster, 2005; Sajady et al., 2088). After purchasing the materials, the system informs the accounts department" of the payable invoice. It is also possible to view any new customer requests and inform the manufacturing, shipping and customer service department therein, and this is one of the characteristics of the quality of AIS. (DeLone \& McLean,2003). Accounting and financial information that is based on storing and processing it, and also on creating reports that can be used in order to make decisions related to the management of the institution. It usually includes the use of electronic data processing equipment, which ensures the achievement of the characteristics of the quality of SIS. It is an integrated system and consists of the following: Users; "people who use the system", and it may include professionals such as accountants, consultants, business analysts, managers, senior financial officials and account auditors, as the AIS system brings these sections together in order to ensure the quality characteristics of AIS (Esmeray, 2016; Fitrios et al., 2018). This, in turn, allows authorized persons to have access into much information on the same system, as well as being communicated to people outside the organization, so the system must be easy to use and help improve performance and increase its efficiency.

Procedures and instructions the methods that are used in order to work on collecting, storing, retrieving and processing data, they may be either manual or automatic, or both. The data comes from internal sources, such as: employees or from external ones, such as: customer requests via the Internet. The procedures and instructions are published either through AIS systems programs, or through documentation and training of employees on using them, and they are constantly updated in order to 
be effective and have the characteristics of the required quality of AIS (Fitriati \& Susanto,2017). Data: defined as financial information related to business in the organization and is used to benefit from and convert into information. So, there should be a database, such as SQL, which is the computer language that is usually used for databases that meet the needs of users of different types of information. Therefore, the quality characteristics of the SIS have to be checked, as the type of data depends on the nature of the business, but it may depend on; sales orders, customer billing data, sales analysis reports, purchase orders, seller bills, records checking, general ledger, stock data, payroll information, timekeeping, information about taxes.

SIS systems programs are computer programs that are used in storing, retrieving, processing and analyzing financial data. All these operations were calculated on paper, but with technological development many programs emerged, such as: Intuit's QuickBooks or 50 Sage's Sage Accounting, to serve accountants and facilitate their work and to ensure the quality characteristics of AIS. It is imperative that the components of the SIS systems program are characterized by quality, reliability and security, as managers rely on the existing information in order to make company decisions based on highquality information. (Saleh et al., 2021b; Šiška, 2016; Fleischman et al., 2010). The infrastructure for information technology is the equipment used to manage the SIS scheme, including laptops, handheld devices, servers, printers, and storage media. They need to be defined by speed and the probability of vast volumes of storage. This equipment should be compliant with the device. To achieve this compatibility, companies are purchasing a "turnkey system" that means that the business will have the perfect mix of hardware and software for the AIS system, and it should also include a plan for hardware maintenance, replacement, development, and disposal of malfunctioning devices.

Internal controls mean the security measures that must be included in the system in order to protect sensitive data, such as: using a password that can be easy or complex and using biological identification (Susanto \& Meiryani,2018). This ensures that the authorized persons have access to computers, often employees of the company itself. Types of AIS systems: electronic data processing makes it easy to take advantage of the characteristics of the quality of SIS and to operate it in a more efficient manner than traditional systems, such as: a manual bookkeeping system. Therefore, computer-based systems are much more useful because they are based on automating many accounting transactions and reducing the incidence of errors in them, ( Flynn,1992).Manual systems: Manual AIS systems are often used by very small companies and home companies, and if the system is entirely manual, many source documents, general ledger, general magazine, private magazines, or sub-journals are required.

Legacy systems (old ones): legacy systems are often present in current business companies and were used before the information technology became sophisticated as it is today. It has some specific advantages for the company, as it contains valuable historical data about the company.

Characteristics of the quality of SIS: financial accounting is based on the creation and collection of useful information for investors, creditors and decision makers, in order to be used in investment and credit decisions, (lavan et al., 2007; Jones,1985; Parkinson et al., 2015; Kaplan,1988). Generally accepted accounting principles require that the financial information is understood by the people who will use it. So, many characteristics have been developed to ensure the correct delivery of information to its users, as the quality characteristics of SIS are distinguished by the following:

Relevance: the usefulness of financial information appears during the decision-making process, so this information must relate to the decisions of the end-users, as other information cannot be used, and work must be taken to exclude it from the financial statements unless it will affect the future decisions of investors or lenders. Therefore, this information must possess the characteristics of the quality of the SIS related to relevance, which must possess three main characteristics, which are: predictive value, feedback and timing (Sadić et al., 2016; Saleh \& Jawabreh, 2020). Predictive value: which enables highquality financial information to be used to establish forecasts and predictions, as past financial records and financial statements can be used to chart performance trends and make expectations about future performance and profitability. Feedback helps users to review financial data and affirm or change their predictions that have been made on past performance patterns, and users can make future decisions based on feedback. Timing: timing is one of the most critical characteristics of significance, as old data will not help customers or creditors in making present or future decisions, as any SIS must be published in a timely manner in order to achieve AIS quality assurance (Kaplan,1988).

Reliability: one of the characteristics of the quality of SIS is the reliability of the financial data, as verification of the financial information of investors and creditors must be consistent and give the same results. In order to be able to use it in decisionmaking, and for this financial information to be reliable, it should have many features, including the following: Verification: the benefit of verification is reaching the same result when using multiple means to measure and evaluate the company's financial statements, and the result must be the same in order to be used in decision-making (Napitupulu et al., 2016).

Comparison is used to compare the company's performance from one year to another, as well as to compare it with competitors., It is, therefore, imperative for this financial information to be prepared in a similar way to provide the ability of comparison, because with its difference it cannot be compared with other data, and the same is true for the currency, as it is not possible compare financial data presented in different currencies with face value. They must be converted into the same currency in order for us to compare them in a useful way (Lestari,2015). 
Consistency: meaning the obligation to use the same accounting procedures in the documentation of related transactions, i.e., to constantly use accounting methods and to conform with the same accounting principles used in the collection of financial data. Consistency refers to the consistency attributes of the SIS because of the ability to have both an interpretation of and the ability to analyze financial data, which in essence provides for the potential of analyzing financial results over various years. Changes in the ways of handling financial data will be worked on but only if they are appropriate and have valid justifications (Kim,1989).

Timelines of AIS: to achieve its quality characteristics and the ability to deliver it on time. Special timetables must be available for this information, in order to provide users of the SIS with enough speed and at the right time to benefit from it and to take necessary action. The importance of deadlines in the quality characteristics of the AIS is illustrated by the following: the preparing of the financial statements at the right time, as consistency of time would be needed to maximize results in a timely manner. Examination of variation by delivering financial results in a timely way, allowing comparisons to be made and thus enabling steps to be taken under the right circumstances. Reporting obligation, as accordance with the schedule, would guarantee consumers regular access to records, and therefore the right to distribute profits and expenditures and the parties responsible for all the operation of the company. Submit supervisory reports that are quarterly or annual, which help to show the discrepancy in a timely manner (Susanto, 2017).

\section{Methodology}

A descriptive approach was followed in the presentation of the results and the analytical approach in the assessment of the results of the analysis aimed at knowing the impact of the accuracy of the outputs of the accounting information system on customer satisfaction in the commercial banks of the KSA. The survey group is the clients of commercial banks operating in the KSA. A random sampling containing 600 respondents from clients was the study poll. In order to arrive at the result in factor analysis we used the SPSS version 20 in analysis 32 items of the Likert scale, before performing axial component analysis, the data's suitability for factor analysis Was evaluated. We observed the presence of several coefficients of 0.3 and above in the correlation matrix. The Kaiser-Meyer-Oklin value was 0.955 , and statistical significance was achieved by the Bartlett's Test of Sphericity, confirming the correlation matrix factorability. Analysis of axial components with Varimax rotation was used. Through by Rotation Sums of Squared Loadings result, we have five items by rotated component matrix was detected the strong loading axial factor.

\subsection{Hypotheses}

$\mathbf{H}_{1}$ : The impact of reliability as a part of the production efficiency of the accounting information system on the level of customer satisfaction with banks operating in the Kingdom of Saudi Arabia is significantly positive.

$\mathbf{H}_{2}$ : The effect between the suitability as a part of the consistency of the performance of the accounting information system and the level of customer satisfaction of the banks operating in the Kingdom of Saudi Arabia is significantly positive.

$\mathbf{H}_{3}$ : The relationship between accuracy as a variable of the efficiency of the performance of the accounting information system and the degree of customer satisfaction with banks operating in the Kingdom of Saudi Arabia is significantly positive.

$\mathbf{H}_{4}$ : Comparability as an aspect of the consistency of the outputs of the accounting information system has a significantly positive impact on the degree of customer satisfaction with banks operating in the Kingdom of Saudi Arabia.

H5: There is a statistically significant effect between the number of the years being customer to the bank as a parameter variable for dealing with banks operating in the Kingdom of Saudi Arabia and the elements of the quality of the outputs of the accounting information system (Relevance, Reliability, Consistency, Comparability).

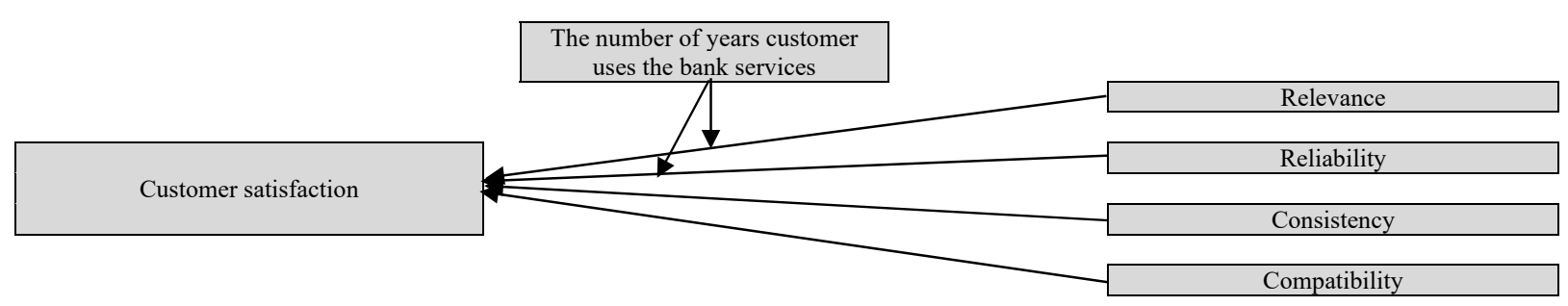

Fig. 1. The proposed study 
$187,31 \%$

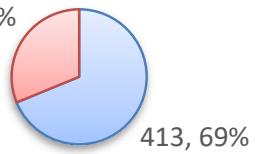

口Male $\square$ Female

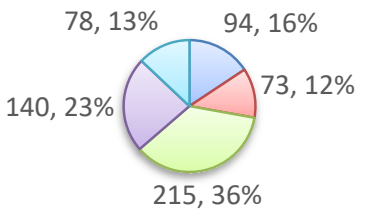

$\square<25 \square 26--35 \square 36--45 \square 46--55 \square>55$
Gender

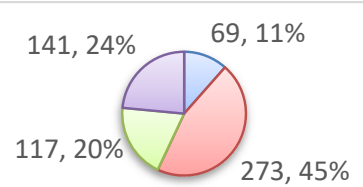

$\square$ Diploma $\square$ Bachelor degree $\square$ Masters degree $\square$ Phs

Educational background
Age

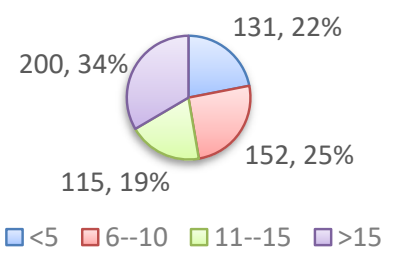

Years of getting services

Fig. 2. Personal characteristics of the participants

Fig. 2 presents details of the personal characteristics of the participants in our survey. As we can observe, most customers have maintained some university educational backgrounds. In addition, a big portion of the clients have been the banks' customers and they were mostly middle-aged people.

\section{Results}

\subsection{Reliability}

Table 1 presents details of the Cronbach's Alpha for the sample of the original study.

\section{Table 1}

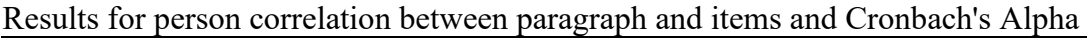

\begin{tabular}{|c|c|c|}
\hline Paragraph & Factor loading & Cronbach's Alpha \\
\hline 1 & 0.811 & \multirow{9}{*}{0.92} \\
\hline 2 & .320 & \\
\hline 3 & .459 & \\
\hline 4 & .530 & \\
\hline 5 & .354 & \\
\hline 6 & .531 & \\
\hline 7 & .514 & \\
\hline 8 & .405 & \\
\hline 9 & .695 & \\
\hline 1 & .701 & \multirow{4}{*}{0.903} \\
\hline 2 & .675 & \\
\hline 3 & .762 & \\
\hline 4 & .724 & \\
\hline 1 & .719 & \multirow{8}{*}{0.927} \\
\hline 2 & .585 & \\
\hline 3 & .591 & \\
\hline 4 & .634 & \\
\hline 5 & .703 & \\
\hline 6 & .709 & \\
\hline 7 & .519 & \\
\hline 8 & 0.688 & \\
\hline 1 & .741 & \multirow{5}{*}{0.905} \\
\hline 2 & .718 & \\
\hline 3 & .631 & \\
\hline 4 & .554 & \\
\hline 5 & .594 & \\
\hline 1 & .311 & \multirow{6}{*}{0.921} \\
\hline 2 & .681 & \\
\hline 3 & .750 & \\
\hline 4 & .772 & \\
\hline 5 & .815 & \\
\hline 6 & .809 & \\
\hline
\end{tabular}


The first hypothesis: There is a statistically significant effect between reliability, as a component of the quality of the output of the accounting information system and the degree of customer satisfaction with banks operating in the Kingdom of Saudi Arabia. To confirm this hypothesis, a simple regression analysis test was performed, as shown in Table 2 as follows,

Table 2

The results of the regression analysis for testing the first hypothesis of the survey

\begin{tabular}{|c|c|c|c|c|c|c|c|c|c|}
\hline \multirow{2}{*}{$\mathrm{R}$} & \multirow{2}{*}{$\begin{array}{c}\mathrm{R} \\
\text { Square }\end{array}$} & \multirow{2}{*}{$\begin{array}{l}\text { Adjusted R } \\
\text { Square }\end{array}$} & \multirow{2}{*}{$\mathrm{F}$} & \multirow{2}{*}{ Sig* } & \multicolumn{5}{|c|}{ Regression coefficients } \\
\hline & & & & & Domain & $\beta$ & Std. Error & $\mathrm{T}$ & Sig* \\
\hline 0.661 & 0.437 & 0.436 & 463.384 & $0.00 *$ & Reliability & 0.661 & 0.037 & 21.526 & $0.000 *$ \\
\hline
\end{tabular}

* Statistically significant at the level of statistical significance $(\alpha \leq 0.05)$

Table 2 indicates that there is a strong association between reliability, as an aspect of the performance efficiency of the accounting information system and the degree of customer satisfaction with operating banks where the correlation coefficient has been reached (0.661). In addition, the findings of the regression analysis revealed a statistically important reliability effect, where the value of (P) 463,384 was less than (0.00) in statistical terms, and this was verified by the (T) test, this means that stability as an aspect of the consistency of the performance of the accounting information system and the degree of customer satisfaction with the operating banks have a positive impact. For an organization, knowledge is a source of power. Knowledge will inform the company of the success of current operating performance and help estimate and strategize how to function in the future. For any professional in any field, the ability to grasp, digest, interpret and filter information is the key to growth and success. Across the organization, information is available. Sales, marketing, human resources, and management need data to run their departments and make regular decisions.

In this analysis, the quality of the MAIS is a specification that can be used as a structure that is incorporated into the business by using the tools to provide managers and workers in an organization with relevant details, both financial and non-financial, for decision-making to achieve goals directly within the organization. The standard of MAIS will satisfy the users of the system itself if the system can meet the needs of users. On one hand, artificial intelligence will contribute to improving the quality characteristics of accounting information, and in speeding up its arrival in real time through several sources. On the other hand, it will increase the collection of big data, to access better one (Wilkinson et al., 2000; Romney et al., 2013). The role of accountants will be making use of this data and transforming it into information to work on increasing the quality characteristics of accounting information. The block chain feature allows access to multiple sources of information by multiple users at the same time. Although these techniques are methods that contribute to facilitating manual transactions, the decision-making and planning processes need experts.

The second hypothesis: the importance as a part of the Relevance of the performance of the accounting information system is statistically significant and the degree of customer satisfaction with the banks operating in the Kingdom of Saudi Arabia is statistically significant.

A basic regression analysis test was conducted to validate this hypothesis, as seen in Table 3 as follows,

Table 3

The results of the regression analysis for testing the second hypothesis of the survey

\begin{tabular}{|c|c|c|c|c|c|c|c|c|c|}
\hline \multirow{2}{*}{$\mathbf{R}$} & \multirow{2}{*}{ R Square } & \multirow{2}{*}{$\begin{array}{l}\text { Adjusted R } \\
\text { Square }\end{array}$} & \multirow{2}{*}{$\mathbf{F}$} & \multirow{2}{*}{ Sig* } & \multicolumn{5}{|c|}{ Regression coefficients } \\
\hline & & & & & Domain & $\beta$ & Std. Error & $\mathbf{T}$ & Sig* \\
\hline 0.66 & 0.447 & 0.446 & 483.37 & $0.00 *$ & Relevance & 0.669 & 0.029 & 21.98 & $.000 *$ \\
\hline
\end{tabular}

* Statistically significant at the level of statistical significance $(\alpha \leq 0.05)$

Table 3 indicates that there is a strong association between significance as a part of the relevance of the performance of the accounting information system and the degree of customer satisfaction with operating banks, where the coefficient of correlation has been achieved (0.669). Regression analysis findings also revealed a statistically important effect of significance, as the value of (q) 483.378 was smaller than (0.00) in statistical terms, and this was verified by the (T) test. The findings also revealed that the difference explained hit (0.446), indicating that the proportion of the suitability effect was 44.6 percent, and the beta value was 44.6 percent $(0.669)$. This means that relevance as an aspect of the consistency of the performance of the accounting information system and the degree of customer satisfaction with the operating banks have a positive impact. 
The third hypothesis: There is a statistically significant effect between consistency as a component of the quality of the output of the accounting information system and the degree of customer satisfaction with banks operating in the Kingdom of Saudi Arabia.

To confirm this hypothesis, a simple regression analysis test was performed, as shown in Table 4.

Table 4

The results of the regression analysis for testing the third hypothesis

\begin{tabular}{|c|c|c|c|c|c|c|c|c|c|}
\hline \multirow[b]{2}{*}{$\mathbf{R}$} & \multirow{2}{*}{$\begin{array}{c}\text { R } \\
\text { Square }\end{array}$} & \multirow{2}{*}{$\begin{array}{c}\text { Adjusted R } \\
\text { Square }\end{array}$} & \multirow[b]{2}{*}{$\mathbf{F}$} & \multirow{2}{*}{ Sig* } & \multicolumn{5}{|c|}{ Regression coefficients } \\
\hline & & & & & Domain & $\boldsymbol{\beta}$ & $\begin{array}{l}\text { Std. } \\
\text { Error }\end{array}$ & $\mathbf{T}$ & Sig* \\
\hline .727 & .529 & .528 & 671.26 & $0.00 *$ & Consistency & .727 & .030 & 25.909 & $.000 *$ \\
\hline
\end{tabular}

Table 4 indicates that there is a strong association between consistency as a part of the consistency of the performance of the accounting information system and the degree of customer satisfaction with operating banks, where the coefficient of correlation has been reached (0.727). The regression analysis results also showed a statistically significant significance effect, where the value of $(\mathrm{F})$ reached $671.268 \mathrm{Sig} .=0.00$, and this was confirmed by the $(\mathrm{T})$ test. The findings also revealed that the variation explained reached $(0.528)$, indicating that the proportion of the stability effect reached (52.8 percent) and the beta value was reached (0.528), meaning that $(0.727)$. This suggests that continuity as an aspect of the level of performance of the accounting information system and the degree of customer satisfaction with the operating banks have a positive effect.

Fourth hypothesis: there is a statistically important impact between the Comparability to be a part of the accounting information system's production quality and the degree of customer loyalty of banks based in the Kingdom of Saudi Arabia

As seen in Table 5, a basic regression analysis test was conducted to validate this hypothesis.

Table 5

The summary of the regression analysis

\begin{tabular}{|c|c|c|c|c|c|c|c|c|c|}
\hline \multirow{2}{*}{$\mathbf{R}$} & \multirow{2}{*}{$\begin{array}{l}\text { R } \\
\text { Square }\end{array}$} & \multirow{2}{*}{$\begin{array}{l}\text { Adjusted R } \\
\text { Square }\end{array}$} & \multirow{2}{*}{$\mathbf{F}$} & \multirow{2}{*}{ Sig* } & \multicolumn{5}{|c|}{ Regression coefficients } \\
\hline & & & & & Domain & $\boldsymbol{\beta}$ & $\begin{array}{l}\text { Std. } \\
\text { Error }\end{array}$ & $\mathbf{T}$ & Sig* \\
\hline 0.78 & 0.615 & 0.614 & 954.37 & $0.00 *$ & Comparability & .784 & .026 & 30.8 & $.000^{*}$ \\
\hline
\end{tabular}

From Table 5, there is a positive correlation of Comparability as a component of the quality of the output of the accounting information system and the degree of customer satisfaction with operating banks, where the correlation coefficient reached (0.784). Also, the results of the regression analysis showed a statistically significant effect of susceptibility, as the value of (P) 954.372), Less than (0.00) in statistical terms, and this was verified by the (T) test. The findings also revealed that the explained variance reached (0.614), indicating that the sensitivity effect reached (61.4 percent) and the beta value was reached (0614) (0.784). This means that portability has a positive effect as a part of the consistency of the accounting information system's performance and the level of customer satisfaction with the operating banks.

Table 8

The summary of the results of R-Square change

Change Statistics

\begin{tabular}{|c|c|c|c|c|c|c|c|c|}
\hline $\mathbf{R}$ & $\begin{array}{l}\text { R } \\
\text { Square }\end{array}$ & $\begin{array}{l}\text { Adjusted R } \\
\text { Square }\end{array}$ & $\begin{array}{l}\text { Std. Error } \\
\text { of the } \\
\text { Estimate }\end{array}$ & $\begin{array}{l}\text { R Square } \\
\text { Change }\end{array}$ & $\begin{array}{l}\text { F } \\
\text { Change }\end{array}$ & df1 & df 2 & $\begin{array}{l}\text { Sig. F } \\
\text { Change }\end{array}$ \\
\hline .811 & .658 & .655 & .45995 & .658 & 228.762 & 5 & 594 & $0.000 *$ \\
\hline
\end{tabular}


Fifth hypothesis: The number of years as a parameter variable for dealing with banks operating in the kingdom of Saudi Arabia and the quality elements of the outputs of the accounting information system have a statistically significant effect (Relevance, Reliability, Consistency, Comparability). A multiple linear regression test was applied to ensure the validity of this hypothesis. this is illustrated by Table 9.

Table 9

The results of multiple regression analysis

\begin{tabular}{|c|c|c|c|c|c|c|c|}
\hline $\mathbf{F}$ & Df & Sig* & $\begin{array}{l}\text { Regression coefficients } \\
\text { Domain }\end{array}$ & $\beta$ & Std. Error & $\mathbf{T}$ & Sig* \\
\hline \multirow{5}{*}{228.762} & \multirow{5}{*}{594} & \multirow{5}{*}{$0.00 *$} & The number of the years being customer to the bank & -.069 & .017 & -2.762 & $.006^{*}$ \\
\hline & & & Reliability & .065 & .063 & 1.236 & $.0217 *$ \\
\hline & & & Relevance & .054 & .044 & 1.155 & $.0248^{*}$ \\
\hline & & & Consistency & .237 & .061 & 4.209 & $.000 *$ \\
\hline & & & Comparability & .517 & .040 & 13.139 & $.000 *$ \\
\hline
\end{tabular}

* Statistically significant at the level of statistical significance $(\alpha \leq 0.05)$

In Table 9, we can see the existence of statistical significance for the coefficients of the standard and non-standard multiple linear regression equation related to the independent variable (number of years, reliability, suitability, stability, susceptibility), and statistical significant less than the level of statistical significance $(\alpha \leq 0.05)$, which indicates the existence of a statistically significant effect between the number of years as a mediating variable for dealing with banks operating in the Kingdom of Saudi Arabia and the elements of the quality of the outputs of the accounting information system(Relevance, Reliability, Consistency, Consistency). In addition, other studies may replicate the results of this study by adding variables, dimensions or metrics used.

\section{Conclusion}

A statistically important reliability effect was revealed by the findings of the regression study, where the value of (P) 463,384 was smaller than (0.00) in statistical terms and this was confirmed by the (T) measure, which implies that stability as an element of the accuracy of the performance of the accounting information system and the degree of customer loyalty of the operating banks is positive. Serving accountants and promoting their practice and maintaining the quality functionality of the AIS (Neogy, 2014; O'Brien \& Marakas,2010). Efficiency, reliability, and protection must be defined by the components of the SIS systems software, as managers depend on current knowledge to make organization decisions dependent on high-quality information.

The results showed that the hit was clarified by the difference (0.446), meaning that the proportion of the suitability effect was 44.6 percent, and the beta benefit was 44.6 percent $(0.669)$. This suggests that there is a positive effect on significance as an element of the quality of the results of the accounting information system and the degree of customer loyalty with operating banks. Relevance: during the decision-making process, the value of financial information emerges, so the information must apply to end-user decisions, as such information cannot be included, and effort must be undertaken to remove it from the financial statements because it influences the potential decisions of borrowers or lenders. Accordingly, the information must have the appropriate quality characteristics of the SIS, which must have three key characteristics. There are: predictive value, input and pacing. Predictive value: enabling high-quality financial knowledge to be used to construct estimates and forecasts, since it is possible to use historical financial reports and financial statements to map performance patterns and generate benchmarks for future performance and profitability, (Ong et al., 2009; Otley, 1980; Pierce \& O'Dea,2003). Feedback helps users to review financial data and affirm or change their predictions that have been made on past performance patterns, and users can make future decisions based on feedback. Timing: timing is one of the most critical characteristics of importance, since the old data would not help customers or borrowers in making present or prospective decisions, since any SIS must be published in a timely manner in order to attain AIS quality assurance.

There is a clear relationship between the accuracy of the output of the accounting information system and the degree of customer satisfaction with operating banks where the correlation coefficient has been reached (0.727). The requirement to use the same accounting procedures in the documentation of related transactions, that is, to constantly use accounting methods and to conform with the same accounting principles used in the collection of financial data. (Salehi \& Abdipour,2011). Consistency refers to the consistency characteristics of the SIS because of its capacity to have both an interpretation and the ability to process financial data, In turn, this provides for the prospect of comparing financial results over various years. Changes in the ways of handling financial data will be worked on but only if they are appropriate and have valid justifications.

A statistically relevant sensitivity effect was demonstrated by the findings of the regression study, as the significance of (P) 954.372) was less than (0.00) in statistical terms, and this was confirmed by the (T) examination. The results also showed that the variance explained reached (0.614), suggesting that the sensitivity effect reached (61.4 percent) and the beta value was achieved (0614) (0.784). This suggests that portability has a beneficial impact as part of the stability of Performance of the accounting information system and customer loyalty standard with the operating banks. Comparison is used to compare the results of the business from one year to another and to compare it with rivals, (Xu, 2009; Saleh et al., 2018). Thus, it is 
important that these financial reports be prepared in a comparability way to have the opportunity to compare, so it cannot be matched with other data with the difference, and the same applies to the currency, since it is not possible to compare finance. In order for us to compare them in a useful manner, they must be translated into the same currency.

\section{References}

Alananzeh, O. A., Masadeh, R., Jawabreh, O., Mahmoud, A. A., \& Hamada, R. (2018). The Impact of Customer Relationship Management on Tourist Satisfaction: The Case of Radisson Blue Resort in Aqaba City. Journal of Environmental Management and Tourism, 9(2), 227. doi: 10.14505//jemt.v9.2(26).02

Bagranoff, N.A., Simkin, M.G., Norman, C.S. (2010). Core concept of accounting information systems (11th ed.). John Wiley \& Sons, Inc.

Bjørnenak, T., \& Olson, O. (1999). Unbundling management accounting innovations. Management Accounting Research, 10(4), 13-32. doi: 10.1006/mare.1999.0110.

Byrne, S., \& Pierce, B. (2007). Towards a more comprehensive understanding of the roles of management accountants. European Accounting Review, 16(3), 469-498. doi: 10.1080/09638180701507114.

Chenhall, R. H., Morris, D. (1986). The impact of structure, environment, and interdependence on the perceived usefulness of management accounting systems. The Accounting Review, 61(1), 16-35.

Corner, R. (1989). Systems analysis for profit’ business applications. Prentice Hall Publishers.

Dalimunthe, A. R., Napitupulu, I. H., Situngkir, A. (2018). The internal control of management accounting information systems of the state-owned enterprises in Indonesia. Achieves of Business Research, 6(6), 303-314.

Davila, A., Foster, G. (2005). Management accounting systems adoption decisions: Evidence and performance implications. The Accounting Review, 80(4), 1039-1068.

DeLone, W. H., \& McLean, E. R. (2003). The DeLone and McLean model of information system success: A ten-year update. Journal of Management Information Systems, 19(4), 9-30.

Esmeray, A. (2016). The impact of accounting information systems on firm performance: Empirical evidence in Turkish small and medium sized enterprises. International Review of Management and Marketing, 6(2), 233-236.

Fitrios, R., Susanto., A., Soemantri, R., Suharman, H. (2018). The influence of environmental uncertainty on the accounting information system quality and its impact on the accounting information quality. Journal of Theoretical and Applied Information Technology, 96(21), 7164-7175.

Fitriati, A., \& Susanto, A. (2017). The accounting information system quality improvement through internal control and top management support effectiveness. Journal of Theoretical and Applied Information Technology, 95(19), 5003-5011.

Fleischman, G., Walker, K., \& Johnson, E. (2010). A field study of user versus provider perceptions of management accounting system services. International Journal of Accounting \& Information Management, 18(3), $252-285$. doi: 10.1108/18347641011068992.

Flynn, D. (1992). Information systems requirements: Determination and analysis. Mcgraw Hill Publishing Company - Hill Book Company.

lavan, M. E., Braescu, M., Dumitru, V., Jinga, G., \& Laptes, R. (2007). The relevance and quality of the accounting information in the managerial decisions. Accounting and Management Information Systems, 6(Supplement), $103-115$.

Jahmani, A., Bourini, I., \& Jawabreh, O. A. (2020). THE RELATIONSHIP BETWEEN SERVICE QUALITY, CLIENT SATISFACTION, PERCEIVED VALUE AND CLIENT LOYALTY: A CASE STUDY OF FLY EMIRATES. Cuadernos De Turismo, (45), 219-238. doi:http://dx.doi.org/ 10.6018/turismo.45.426101.

Jawabreh,O. Al Sarayreh, M .(2017). Analysis of job satisfaction in the hotel industry: A study of hotels five- Stars in Aqaba special economic zone authority (AZEZA), International Journal of Applied Business andEconomic Research,15 19 (Part-II), 407 - pp.389.

Jawabreh,O,. Jahmani ,A,.Khaleefah,Q,. Alshatnawi,E,.Abdelrazaqe,H.(2020). Customer Expectation in Five Star Hotels in Aqaba Special Economic Zone Authority (ASEZA), International Journal of Innovation, Creativity and Change, Volume 11, Issue 4.

Jones, C. S. (1985). An empirical study of the role of management accounting systems following takeover or merger. Accounting Organizations and Society, 10(2), 177-200.

Kaplan, R. S., \& Atkinson, A. A. (1998). Advanced management accounting (3rd ed.). Prentice Hall International.

Kim, K. K. (1989). User satisfaction: A synthesis of three different perspectives. Journal of Information Systems, Fall, 112.

Lestari, R. (2015). The influence of manager competence on the quality of management accounting information system and its implications on the quality of management accounting information. International Journal of Applied Business and Economic Research, 13(6), 4405-4416.

Masadeh, R., Alananzeh, O., Jawabreh, O., Alhalabi, R., Syam, H., \& Keswani, F. (2019). The association among employee's communication skills, image formation and tourist behaviour: perceptions of hospitality management students in Jordan. International Journal of Culture, Tourism and Hospitality Research, 13(3), 257-272. doi: 10.1108/ijcthr-02-2018-0028

Napitupulu, I. H. (2015). Antecedence of user satisfaction in management accounting information systems quality: User involvement and user competency (survey of indonesia manufacture company managers). International Journal of Applied Business and Economic Research, 13(2), 561-577. 
Napitupulu, I. H., Mahyuni, S., Sibarani, J. L. (2016). The impact of internal control effectiveness to the quality of management accounting information system: The survey on state-owned enterprises (soes). Journal of Theoretical and Applied Information Technology, 88(2), 358-366.

Neogy, T. K. (2014). Evaluation of efficiency of accounting information systems: A study on mobile telecommunication companies in Bangladesh. Global Disclosure of Economics and Business, 3(1), 40-55.

O’Brien, J. A., Marakas, G. M. (2010). Introduction to information systems (15th ed.). McGrew-Hill Irwin.

Ong, C. S., Day, M. Y., Hsu, W. L. (2009). The measurement of user satisfaction with question answering systems. Information \& Management, 46, 397-403.

Otley, D. (1980). The contingency theory of management accounting: Achievements and prognosis. Accounting Organisations and Society, 5(3), 251-267.

Parkinson, J. M., Riro, G. K., \& Waweru, N. M. (2015). Need for accounting information systems in small-scale Kenyan businesses. Transnational Corporations Review, 7(4), 425-440.

Pierce, B., \& O’Dea, T. (2003). Management accounting information and the needs of managers: Perceptions of managers and accountants compared. The British Accounting Review, 35(3), 257-290. doi: 10.1016/S0890-8389(03)00029-5

Romney, M. B., Steinbart, P. J., Mula, J. $\quad$ M., McNamara, R., \& Tonkin, T. (2013). Accounting information systems (1st ed.). Australia: Pearson Education, Inc.

Sadić, S., Puśkak, A., \& Beganović, A. (2016). Information support model and its impact on utility, satisfaction and loyalty of user. The European Journal of Applied Economics, 13(2), 30-44.

Saleh, M. M. A., \& Jawabreh, O. A. A. (2020). Role of Environmental Awareness in The Application of Environmental Accounting Disclosure In Tourism And Hotel Companies And Its Impact OnInvestor'S Decisions In Amman Stock Exchange. International Journal of Energy Economics and Policy, 10(2), 417-426. doi: 10.32479/ijeep.8608

Saleh, M. M. A., , Jawabreh, O. A. A., Alsarayreh, M. N., Malkawi, E . (2018). Environmental accounting as perspective for hotels of Aqaba special economic zone authority (ASEZA). Problems and Perspectives in Management, 16(4), 169185. doi: $10.21511 / \mathrm{ppm} .16(4) .2018 .15$

Saleh, M., Jawabreh, O,. Al-Amro, S., \& Saleh, H. (2021a). Requirements for enhancing the standard of accounting education and its alignment with labor market requirements a case study hospitality and industrial sector in Jordan, Journal of Sustainable Finance \& Investment, DOI: 10.1080/20430795.2021.1891781

Saleh, M., Jawabreh, O., \& E Abu-Eker, E., (2021b) Factors of applying creative accounting and its impact on the quality of financial statements in Jordanian hotels, sustainable practices, Journal of Sustainable Finance \& Investment, DOI: 10.1080/20430795.2021.1962662

Salehi, M., \& Abdipour, A. (2011). A study of the barriers of implementation of accounting information system: Case of listed companies in Tehran stock exchange. Journal of Economic Behavior and Organization, 2, 76-85.

Salehi, M., Rostami, V. and Mogadam, A. (2010). Usefulness of accounting information system in emerging economy: empirical evidence of Iran. International Journal of Economics and Finance, 2(2).

Sajady, H., Dastgir, M., Nejad, H. H. (2008). Evaluation of the effectiveness of accounting information systems. International Journal of Information Science and Technology, 6(2), 49-59.

Šiška, L. (2016). The contingency factors affecting management accounting in Czech companies. Acta Universitatis Agriculturae et Silviculturae Mendelianae Brunensis, 64(4), 1320-1383. doi: 10.11118/actaun201664041383

Situngkir, A., Napitupulu, I. H. (2019). The quality of management accounting information system is the key increasing user satisfaction of information systems: Evidence of state owned enterprises (SOEs) in Indonesia. Quality Access to Success, 20(173), 145-150.

Susanto, A. (2017). The empirical testing how the quality of accounting information systems affected by organizational structure research at universities in Bandung. Asian Journal of Information Technology, 16(1), 1098-1105.

Susanto, A., Meiryani. (2018). The quality of accounting information system and its impact on the quality of accounting information: User ability and top management support. Journal of Engineering and Applied Sciences, 13(2), $384-387$.

Wilkinson, J. W., Cerullo, M. J., Raval, V., \& Bernard, W. W. (2000). Accounting information systems-Essential concepts and applications (4th ed.). John Wiley.

$\mathrm{Xu}$, H. (2009). Data quality issues for accounting information systems' implementation: Systems, stakeholders, and organizational factors. Journal of Technology Research, 1, 1-11.

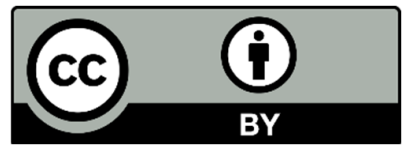

(C) 2022 by the authors; licensee Growing Science, Canada. This is an open access article distributed under the terms and conditions of the Creative Commons Attribution (CC-BY) license (http://creativecommons.org/licenses/by/4.0/). 